\title{
PENGEMBANGAN MEDIA BELAJAR ALBUM STIKER MASUK DAN BERKEMBANGNYA PENGARUH HINDU BUDHA DI INDONESIA SEBAGAI BAHAN AJAR PENDUKUNG MATA KULIAH SEJARAH NASIONAL INDONESIA I PROGRAM STUDI PENDIDIKAN SEJARAH DAN SOSIOLOGI IKIP BUDI UTOMO MALANG
}

Irvan lestari*1, Ari Nugrahani ${ }^{2}$

1,2 IKIP Budi Utomo Malang

\begin{tabular}{l}
\hline \hline Article Info \\
\hline Article history: \\
Received Nov 13, 2020 \\
Accepted April 22, 2021 \\
Published April, 2020 \\
\end{tabular}

\section{Keywords:}

Learning Media, Sticker Album, History Subject

\begin{abstract}
Teaching challenges today require that teachers be able to present interesting learning media innovations. Likewise, in history learning, it is necessary to use innovative media so that students have an interest and interest in historical material. The Indonesian National History course I am a course that allows the use of teaching materials in the form of sticker album media. Broadly speaking, media can be humans, materials, or events that cause students to be able to acquire knowledge, skills or attitudes. The media complements other media in the form of textbooks as well as a learning environment in the form of a campus environment and its infrastructure and facilities. After analyzing the results of interviews and observations, the presence of learning media in the form of sticker albums is quite effective in facilitating lecture activities in general and facilitating the assessment of student assignments in particular. More than that, its presence can make history learning activities not monotonous in the sense that learning activities are centred on lecturers who use the lecture method while students listen passively.
\end{abstract}

Copyright $@ 2021$ FKIP UMP All right reserved

\section{Corresponding Author:}

Irvan Lestari,

Pendidikan Sejarah dan Sosiologi,

IKIP Budi Utomo Malang,

J1. Simpang Arjuno No.14B, Kauman, Kec. Kajen, Kota Malang, indonesia

Email: irvan_ibu@yahoo.com

\section{How to Cite:}

Lestari, I., Nugrahani, A. (2021). Pengembangan Media Belajar Album Stiker Masuk dan Berkembangnya Pengaruh Hindu Budha di Indonesia Sebagai Bahan Ajar Pendukung Mata Kuliah Sejarah Nasional Indonesia I Program Studi Pendidikan Sejarah dan Sosiologi IKIP Budi Utomo Malang. Khazanah Pendidikan-Jurnal Ilmiah Kependidikan (JIK), 15(1), 8-13. 


\section{PENDAHULUAN}

Dewasa ini seiring dengan perkembangan teknologi yang penuh tantangan dan menuntut inovasi. Salah satu tantangan tersebut ada dalam dunia pendidikan, maka dibutuhkan pula kehadiran inovasi dengan menggunakan media belajar dalam kegiatan belajar mengajar di ruang kelas. Hal tersebut dimaksudkan agar pembelajaran menjadi lebih efektif sekaligus menarik minat peserta didik. Demikian pula dalam pembelajaran sejarah perlu pula digunakan media yang inovatif agar peserta didik memiliki minat dan ketertarikan terhadap materi sejarah. Mata kuliah Sejarah Nasional Indonesia I merupakan mata kuliah yang memungkinkan untuk menggunakan bahan ajar berupa media album stiker. Sebuah media belajar yang membuat peserta didik untuk belajar tidak hanya dengan mendengar dosen berceramah dan sekadar diskusi, melainkan juga ada keterlibatan aktif peserta didik untuk menyelesaikan tugas dengan mengerjakan buku tugas yang berupa media dengan nama album stiker dengan tema sejarah masuk dan berkembangnya pengaruh Hindu Budha di Indonesia. Media album stiker merupakan buku tugas yang didesain dengan inovatif, berisi materi deskripsi tentang sejarah masuknya pengaruh Hindu Budha. Menjelaskan teoriteori masuknya agama Hindu beserta kelemahan dan dasar argumen teori tersebut. Menjabarkan kerajaan beserta peninggalan-peninggalan masa Hindu Budha. Buku tugas album stiker tersebut menuntut kecermatan peserta didik untuk menempelkan stiker album berupa gambar yang sesuai dengan deskripsi yang ada.

Kehadiran media belajar di tengah perkembangan inovasi dalam dunia teknologi pendidikan merupakan suatu keniscayaan. Media belajar memiliki peranan untuk menumbuhkan minat dan mengembangkan rasa ingin tahu peserta didik akan materi yang sedang dipelajarinya. Dalam penelitian ini materi yang dimaksudkan adalah sejarah masuk dan berkembangnya pengaruh Hindu Budha di Indonesia. Selama ini ada suatu pendapat yang banyak dikemukakan oleh para pendidik dan ahli pendidikan jika kegiatan belajar mengajar seringkali dilakukan dengan cara monoton dan konvensional. Dalam artian guru atau dosen lebih sering menggunakan metode ceramah dan diskusi di kelas. Tidak salah memang, hanya saja ketika hal itu dilakukan maka ada satu aspek dalam kegiatan belajar yang lebih ditonjolkan dan ada aspek lain yang tanpa sengaja terpinggirkan. Hal yang lebih menonjol dalam kegiatan belajar mengajar yang berupa ceramah adalah peranan guru atau dosen sebagai pengajar, dan yang terpinggirkan tentu saja peranan peserta didik. Padahal peserta didik tidak dapat hanya diperlakukan hanya sebagai dan sebatas objek belajar ia juga harus dapat berperan sebagai subjek belajar. Terlebih di perguruan tinggi dimana peserta didiknya merupakan mahasiswa yang sudah berusia dewasa dan matang pikirannya. Atas dasar latar belakang demikian maka perlu dibuat media belajar album stiker masuk dan berkembangnya pengaruh Hindu Budha di Indonesia sebagai bahan ajar pendukung untuk mata kuliah Sejarah Nasional Indonesia I.

Berangkat dari latar belakang di atas maka peneliti melakukan penelitian dengan judul "Pengembangan Media Belajar Album Stiker Masuk dan Berkembangnya Pengaruh Hindu Budha di Indonesia Sebagai Bahan Ajar Pendukung Mata Kuliah Sejarah Nasional Indonesia I Program Studi Pendidikan Sejarah dan Sosiologi IKIP Budi Utomo Malang."Tujuan penelitian ini adalah. Pertama, menghasilkan model berupa media album stiker masuk dan berkembangnya pengaruh Hindu Budha di Indonesia sebagai bahan ajar pendukung mata kuliah Sejarah Nasional Indonesia I. Kedua, untuk mengetahui efektif tidaknya serta sisi penerimaan penggunaan media pembelajaran album stiker masuk dan berkembangnya pengaruh Hindu Budha di Indonesia yang digunakan sebagai bahan ajar pendukung mahasiswa pendidikan sejarah dan sosiologi IKIP Budi Utomo Malang. Dikarenakan suasana pandemi covid19 maka kegiatan pembelajaran tidak dapat dilakukan secara normal. Untuk mempermudah pengambilan data maka penelitian ini merupakan penelitian kualitatif deskriptif. 
a. Pengertian Media

Kata media merupakan bentuk jamak dari kata medium yang berarti perantara atau pengantar (Oka, 2017:4). Secara garis besar media dapat berupa manusia, materi, atau kejadian yang menyebabkan siswa mampu memperoleh pengetahuan, keterampilan, atau sikap. Dalam pengertian ini dosen, teman sebaya sesama mahasiswa dan buku teks serta lingkungan belajar berupa lingkungan kampus beserta prasarana dan sarananya dapat masukkan dalam pengertian media.

b. Pengertian Media Belajar

Media belajar memiliki pengertian sebagai alat bantu yang berguna dalam kegiatan belajar mengajar. Alat bantu tersebut dapat mewakili sesuatu yang tidak dapat disampaikan oleh pengajar (Dosen atau Guru) melalui kata-kata atau kalimat. Salah satu alasan digunakannya media belajar adalah untuk mengatasi permasalahan lemahnya daya serap siswa terhadap bahan pelajaran yang sulit dan rumit untuk dimengerti oleh peserta didik (Nugrahani, 2007:36). Pengertian lain dari media pembelajaran adalah segala sesuatu yang menyangkut software dan hardware yang dapat digunakan untuk menyampaikan isi materi ajar dari sumber pembelajaran ke peserta didik (individu atau kelompok), yang dapat merangsang pikiran, perasaan, perhatian dan minat pembelajar sehingga proses pembelajaran menjadi lebih efektif (Jalinus dan Ambiyar, 2016:2-4).

c. Klasifikasi Media Belajar

Media belajar dapat diklasifikasikan setidaknya menjadi tiga jenis. Yaitu media grafis, media audio dan media realita. Media grafis merupakan media visual yang menyajikan fakta, ide, atau gagasan melalui penyajian kata-kata, kalimat, angka-angka dan simbol atau gambar. Tujuannya adalah untuk memperjelas sajian ide dan mengilustrasikan fakta-fakta sehingga mudah untuk diingat. Contohnya adalah poster, foto, filmstrip. Media audio merupakan media yang penyampaian pesannya hanya dapat diterima oleh indra pendengaran. Jenis media audio diantaranya adalah radio, tape recorder, dan dewasa ini juga dapat menggunakan smartphone. Sedangkan yang terakhir adalah media realita, yaitu media nyata yang ada di lingkungan alam, baik digunakan dalam keadaan hidup maupun sudah diawetkan, seperti: binatang, spesimen, herbarium. Untuk pembelajaran sejarah miniatur candi, diorama dan benda-benda sejarah termasuk media realita yang dapat digunakan sebagai alat untuk membantu peserta didik memahami materi sejarah dengan lebih baik.

d. Kegunaan dan Tujuan Media Belajar

Pada dasarnya penggunaan media belajar merupakan upaya pengajar untuk mengatasi masalah dalam kegiatan belajar mengajar. Adanya sikap bosan manakala cara penyampaian materi yang dilakukan oleh guru atau dosen hanya menggunakan metode ceramah atau diskusi. Rasa bosan tersebut menuntut digunakannya penggunaan metode mengajar yang lebih beragam. Selain itu penggunaan media dapat meningkatkan nilai ujian peserta didik jika dilakukan dengan tepat. Hal ini disebabkan karena pemakaian media belajar dapat membangkitkan keinginan dan minat peserta didik, membangkitkan motivasi dan rangsangan kegiatan akan kegiatan belajar, dan bahkan membawa pengaruh-pengaruh psikologis yang baik terhadap siswa (Hamalik, 1986). Adalah hal yang tidak dapat di pungkiri dalam dunia pendidikan jika seorang siswa merasa senang dengan apa yang dilakukannya maka hasil diperolehnya akan baik.

e. Media Belajar Album Stiker

Merupakan alat bantu untuk menyampaikan materi masuk dan berkembangnya pengaruh Hindu Budha di Indonesia. Sekaligus sebagai buku tugas yang digunakan sebagai bahan ajar tambahan mata kuliah Sejarah Nasional Indonesia I. Berisi penjelasan masuk dan berkembangnya pengaruh Hindu Budha di Indonesia dengan dilampiri stiker gambar yang relevan, yang mewakili materi sejarah masuk dan 
berkembangnya pengaruh Hindu Budha di Indonesia yang dibahas dalam mata kuliah SNI I. Stiker tersebut untuk ditempel dengan mencocokkan gambar dengan penjelasan yang ada pada album.

f. Pengaruh Hindu Budha

Yang dimaksud dengan pengaruh Hindu Budha adalah suatu masa tertentu dalam sejarah Indonesia dimana agama Hindu Budha dan kebudayaan yang berasal dari pengaruh agama tersebut telah sampai ke Indonesia atau Nusantara. Periode ini dimulai dari abad I sampai abad XVI (Suwardono, 2013:4-5). Agama Hindu merupakan bentuk percampuran kepercayaan antara bangsa Arya dengan bangsa Dravida yang lahir dan berkembang di India. Agama Hindu bersifat politeisme, yaitu percaya kepada beberapa dewa. Tiga dewa utama yang dipuja oleh masyarakat Hindu adalah Dewa Brahmana (dewa pencipta), Dewa Wisnu (dewa pemelihara), dan Dewa Syiwa (dewa pelebur). Ketiga dewa itu dikenal dengan sebutan Trimurti. Kitab suci agama Hindu adalah Weda. Masyarakat Hindu terbagi dalam empat golongan yang disebut kasta. Keempat kasta tersebut adalah kasta Brahmana, kasta Ksatria, kasta Waisya, dan kasta Sudra. Di luar keempat kasta tersebut masih ada golongan masyarakat yang tidak termasuk dalam kasta, yaitu mereka yang masuk dalam kelompok Paria. Kasta Brahmana merupakan kasta tertinggi. Kaum Brahmana bertugas menjalankan upacara-upacara keagamaan. Kasta Ksatria merupakan kasta yang bertugas menjalankan pemerintahan. Golongan raja, bangsawan dan prajurit masuk dalam kelompok kasta Kstaria ini. Kasta Waisya merupakan kasta dari rakyat biasa, yaitu para petani dan pedagang. Adapun kasta Sudra adalah kasta dari golongan hamba sahaya atau para budak. Sementara itu, golongan Paria merupakan golongan yang tidak diterima dalam kasta masyarakat Hindu (Sudrajat, 2012:2). Masuknya agama Hindu Budha ke Indonesia belum dapat diketahui secara pasti. Namun, pada tahun $400 \mathrm{M}$ dapat dipastikan jika agama Hindu Budha telah masuk serta berkembang di Indonesia. Hal ini dibuktikan dengan penemuan prasasti pada Yupa di Kalimantan Timur. Prasasti tersebut menunjukkan bahwa telah berkembang kerajaan Kutai di Kalimantan Timur. Dengan adanya kerajaan pada tahun 400 M, berarti agama Hindu Budha masuk ke Indonesia sebelum masa tersebut (Sudrajat, 2012:2 dan Suwardono, 2013: 5-13).

g. Sejarah Nasional Indonesia I

Sejarah Nasional I merupakan mata kuliah yang ada di IKIP Budi Utomo Malang yang membahas tentang proses masuk dan berkembangnya pengaruh Hindu Budha di Indonesia. Dengan kurun waktu bahasan sejak berakhirnya masa praaksara sampai masuk dan berkembangnya kerajaan Islam beserta munculnya kolonialisme di Indonesia. Merupakan mata kuliah yang wajib ditempuh oleh mahasiswa program studi pendidikan sejarah dan sosiologi sebagai kelanjutan dari mata kuliah wajib sebelumnya yaitu Prasejarah Indonesia.

\section{METODE}

Secara umum metode penelitian didefinisikan sebagai suatu kegiatan ilmiah yang terencana, terstruktur dan sistematis serta memiliki tujuan baik secara praktis maupun teoritis. Dengan sifatnya yang ilmiah karena didasarkan pada ilmu pengetahuan dan teori. Terencana karena penelitian wajib dilakukan dengan memperhatikan waktu, dana serta aksebilitas terhadap tempat dan data (Raco, 2010:54-55). Dikarenakan suasana pandemi covid19 maka kegiatan pembelajaran tidak dapat dilakukan secara normal atau seperti biasanya dimana sebagian besar kegiatan pembelajaran dilakukan secara daring. Maka untuk mempermudah pengumpulan serta pengolahan data, metode penelitian ini menggunakan pendekatan kualitatif deskriptif, dimana data yang diambil dari wawancara dengan 
mahasiswa yang sedang menerima matakuliah Sejarah Nasional serta studi pustaka. Metode deskriptif berusaha memaparkan fakta-fakta yang kemudian dianalisis.

Teknik pengumpulan data merupakan cara atau teknik yang digunakan penulis untuk mendapatkan data atau informasi. Data penelitian merupakan segala fakta dan fenomena. Adapun teknik yang digunakan untuk mendapatkan informasi adalah wawancara serta menggunakan dokumentasi. Penelitian ini menempuh beberapa tahapan sebagai berikut; Pertama, Identifikasi dan perumusan masalah. Kedua, Menentukan tujuan penelitian. Ketiga, pengumpulan data meliputi kegiatan observasi, wawancara dan dokumentasi. Keempat, pengolahan data dan analisis data. Kelima, membuat deskripsi dan kesimpulan.

\section{HASIL DAN PEMBAHASAN}

Media belajar berupa album stiker masuk dan berkembangnya agama Hindu-Budha di Indonesia rupanya disambut positif oleh mahasiswa program studi pendidikan sejarah dan sosiologi. Serta mendapat apresiasi dari dosen-dosen di lingkup program studi yang merupakan rekan-rekan sejawat penulis. Kehadiran media album stiker menambah media belajar yang ada di laboratorium sejarah IKIP Budi Utoma Malang serta dapat menjadi bahan rujukan mahasiswa yang menempuh matakuliah Sejarah Nasional Indonesia 1. Media belajar album stiker tersebut mudah untuk digandakan dan tidak membutuhkan perangkat teknologi yang canggih semacam gawai karena berupa media cetak. Hal tersebut merupakan suatu keunggulan mengingat keterbatasan perangkat komunikasi dan pembelajaran mahasiswa yang terbatas. Namun, meskipun media tersebut berupa media cetak penulis sebagai peneliti yang merancang media tersebut tetap membuat soft file nya sehingga dapat digandakan oleh siapa pun yang membutuhkan dan memerlukannya.

Pengembangan media belajar berupa album stiker yang telah dikembangkan sudah melewati tahap validasi oleh validator dan dinyatakan valid oleh validator untuk diuji cobakan kepada mahasiswa program studi pendidikan sejarah dan sosiologi yang sedang menempuh matakuliah sejarah nasional Indonesia 1. Pembelajaran yang berkualitas menuntut adanya media pembelajaran. Manfaat media album stiker di satu sisi membuat kegiatan belajar lebih memberi porsi pada peserta didik sehingga mahasiswa sebagai peserta didik tidak hanya sebagai objek belajar melainkan mampu menjadi subjek belajar. Dengan demikian di dalam ruang kelas dosen sebagai pengampu mata kuliah dapat berperan sebagai fasilitator, mediator dan manajer dari sebuah proses pembelajaran, aktivitas belajar pun menjadi lebih aktif bagi peserta didik. Dalam hal keaktifan peserta didik media pembelajaran ini memaksa mahasiswa untuk aktif mencocokkan antara gambar yang tersedia sebagai stiker dengan keterangan yang terdapat dalam album. Di tengah pembelajaran daring saat ini buku album stiker dapat menjadi buku tugas yang wajib dikerjakan mahasiswa. Nilai tambah yang dapat diberikan untuk pelaksanaan perkuliahan adalah dalam hal penugasan yang tidak menuntut untuk selalu online mengingat perkuliahan online memerlukan kuota internet yang tidak murah. Kemudian tugas tersebut dapat difoto setelah dikerjakan untuk kemudian dikirimkan dengan media WhatsApp ataupun email.

Keunggulan lain yang didapat mahasiswa berdasarkan hasil wawancara adalah memperjelas deskripsi berupa uraian tertulis yang ada di buku referensi ataupun sumber online. Karena menyajikan gambar yang cukup menarik dan memberi informasi tambahan. Gambar-gambar yang digunakan sebagai stiker cukup familier dengan peserta didik. Sebagian gambar tersebut telah dijumpai oleh peserta didik di buku pelajaran SMA ataupun pada buku-buku yang membahas sejarah hindu-budha secara umum. Bahkan menurut mahasiswa tidak jarang gambar yang ada di stiker mereka jumpai saat melakukan kegiatan sinau wisata saat berada di sekolah dulu. Setelah dilakukan analisis terhadap hasil wawancara dan observasi, maka kehadiran media belajar berupa album stiker ini cukup efektif dalam mempermudah kegiatan perkuliahan secara umum dan mempermudah dalam 
aspek penilaian tugas mahasiswa secara khusus. Lebih dari itu kehadiran nya dapat membuat kegiatan belajar sejarah tidak monoton dalam arti kegiatan belajar terpusat pada dosen yang menggunakan metode ceramah sementara mahasiswa pasif mendengarkan saja. Terlebih di saat pembelajaran dilakukan secara daring kegiatan ceramah hanya dapat dilakukan dengan media berbasis online dengan bantuan aplikasi zoom atau google met dan kedua aplikasi tersebut membutuhkan biaya karena menggunakan kota internet. Ditambah jangkauan internet yang tidak merata yang tentu dialami dan dirasakan oleh sebagian mahasiswa. Oleh karena itu media cetak dapat menjadi solusi dari masalah tersebut.

\section{KESIMPULAN}

Kehadiran media belajar di tengah perkembangan inovasi dalam dunia teknologi pendidikan merupakan suatu keniscayaan. Media belajar memiliki peranan untuk menumbuhkan minat dan mengembangkan rasa ingin tahu peserta didik akan materi yang sedang dipelajarinya. Dalam penelitian ini materi yang dimaksudkan adalah sejarah masuk dan berkembangnya pengaruh Hindu Budha di Indonesia. Dengan kehadiran media belajar album stiker selain mampu menghadirkan kegiatan belajar yang lebih inovatif, juga mampu menambah bahan ajar.

Dari hasil analisis data dapat ditarik sebuah simpulan bahwa di IKIP Budi Utomo kehadiran album stiker mendapat sambutan positif dari para dosen di lingkungan program studi pendidikan sejarah dan sosiologi. Selain itu, kehadiran media tersebut membantu kegiatan belajar mengajar di tengah pandemi coviid19 yang memaksa perkuliahan tidak dapat dilakukan secara tatap muka. Bagi mahasiswa kegiatan belajar dirasa lebih beragam dan membuat mahasiswa aktif. Metode ceramah tidak lagi dominan karena juga dapat dilakukan diskusi kelompok sebagai bagian perkulihan. Serta diskusi juga dapat membahas hasil pengerjaan album stiker

\section{DAFTAR PUSTAKA}

Arikunto, S. (2013). Prosedur Penelitian: Suatu Pendekatan Praktik. Jakarta: Rineka Cipta. Jalinus, N., Ambiyar. (2016). Media dan Sumber Pembelajaran. Jakarta: Kencana.

Nugrahani, R. (2007). Media Pembelajaran Berbasis Visual Berbentuk Permainan Ular Tangga Untuk Meningkatkan Kualitas Belajar Mengajar di Sekolah Dasar. Lembaran Ilmu Kependidikan Jilid 36, No. 1, Juni 2007. (online) (https://journal.unnes.ac.id/nju/index.php/LIK/article/view/524), diakses 15 Agustus 2019.

Oka, G. P. A. (2017). Media dan Multimedia Pembelajaran. Yogyakarta: Deepublish.

Raco, J.R. (2010). Metode Penelitian Kualitatif: Jenis, Karakteristik dan Keunggulannya. Jakarta: Grasindo.

Sugiyono. (2014). Metode Penelitian Pendidikan Pendekatan Kuantitatif, Kualitatif dan $R \& D$. Bandung: Alfabeta.

Suwardono. (2013). Sejarah Indonesia Masa Hindu Budha. Yogyakarta: Ombak.

Sudrajat. (2012). Sejarah Indonesia Masa Hindu Budha. Diktat Kuliah. Tidak Diterbitkan.

\section{http://jurnalnasional.ump.ac.id/index.php/khazanah}

